\title{
Study on the Long-term Education Mechanism of the Party Construction among College Students
}

\author{
Fengqiu Jin \\ Harbin Institute of Technology \\ Harbin, China
}

\author{
Zongyi Yang \\ Harbin Institute of Technology \\ Harbin, China
}

\begin{abstract}
For a long time, the party construction in colleges and universities has gained fruitful results, but in the new situation, there are some problems that cannot be ignored. It is of great theoretical and practical significance to construct the long-term education mechanism of party construction among college students, explore the new ideas and new ways of party construction among students, and enhance the effectiveness of party construction among college students and education.
\end{abstract}

Keywords -colleges; party construction among students; party members education and training; long-term mechanism

\section{INTRODUCTION}

$\mathrm{Xi}$ Jinping stressed the great significance and basic requirements of continuous strengthening and improving the ideological and political work in colleges under the new situation at the national ideological and political work conference. In the colleges, party organization is the subject that carries out the ideological and political work. The party construction is the leader and supporting power of ideological and political work, of which the level directly determines the level of ideological and political work. Therefore, it is of great theoretical and practical significance to build the scientific long-term education mechanism of party construction in colleges and put forward the new ideas and new ways of party construction work in colleges based on educating people and combining with the objective developing regulation of ideological and political work and inherent requirements of party construction among students.

\section{The MaIn PROBLEMS IN THE CURRENT PARTY CONSTRUCTION AMONG COLLEGE STUDENTS}

\section{A. The Degree of Specialization of the Workforce is not Enough, with Mostly Part-time workers}

The Party Organization of department is the Basis for the Party Construction among College Students. But in departments, there is often rare full-time staff in charge of party affairs, so most of them are charged by the counselors. Generally a counselor serve as the head of the party construction work concurrently in the department, and take charge of the overall party construction work among the hundreds of students. When it comes to the grades, the grade counselors are responsible for the party construction work of their respective grades. Since the content of daily work of the counselors is complicated, which includes ideological construction of students, class construction, construction of study style, selection of award and scholarship, evaluation and commendation, mental health counseling, telephone home visits, and dealing with all kinds of emergencies, etc. They should also take into account the other tasks assigned by the leaders of the departments. Therefore, when they carry out the party construction work, it is inevitable that they can't make efforts and will only stay in the level of developing party members while lack the systematic thinking and planning on party construction work and thus achieve limited results.

\section{B. Work Content is not Comprehensive, which Emphasizes Development while Neglects Education}

Because the working teams of party construction are mainly part-time workers, the situation of counselors failing in considering comprehensively and party construction work among students pursues development while neglects education is still widespread. The focus of the party construction work is completely on the developing party members, with little attention for education issues of the preparatory party members and formal party members. Most party members training are only formality, of which the course content is obscure and boring, so it is difficult to play a better role of education and training.

At the same time, there are some problems in the process of developing party members. For example, academic record and other "hardware conditions" are often taken as determination of developing party members while inspection on the ideological state and other "software conditions" is not enough, making many students misunderstand that "as long as the academic performance is good, they can join the party", which greatly weakened the ideological education function of party construction work and make the development of party members a disguised scholarship selection.

\section{Work Pattern is not Scientific Enough with Low Degree of Informatization}

In recent years, with the rapid development of Internet technology, multimedia education, online education, distance education, etc. has been widely applied in the professional classroom of universities. But in the party construction among students, the basic education method still remains in the level of "listening to the report and read the document". Although the red website and red WeChat public platform have been established, but there are still some common problems such as 
behind time update, or single content forum set and unclear features and so on, which cannot achieve good educational results.

At the same time, in the information management of student party members, paper archiving and manual retrieval method is still widely used, with low degree of informatization. Students' party activists and party members often have to fill in the basic personal data repeatedly, which not only have low efficiency, but also tend to lead to the situation that multiple material data does not match each other.

\section{The Work Efficiency is not Sustained and the Typical Practice Failed to be Promoted Timely}

As a grassroots party organization in colleges, the party organizations of departments directly carry out the party construction work facing students, so their working state directly determines the overall level of the party construction work of college students. Due to the degree of recognition of party and government leaders of each department, differences of the basis of party construction work and the composition of the working staff, the level of party construction work is also quite different. Among them, some departments actively make innovation in the student party construction work, and achieved good results. These typical practices are often commended throughout the school, but the degree of promotion is far from enough. This phenomenon often leads to two problems: First, for the departments with lower level of party construction work, they can only appreciate the typical practices for the lack of guidance in operational level, so it is difficult to apply in practical work; Second, for these departments that are widely publicized, work ideas of student party construction will change due to the replacement of the leaders of the party committee and changes in the work staff, which makes some typical practices "short-lived" and fail to form a tradition.

\section{STUDY ON THE LONG-TERM MECHANISM OF THE PARTY CONSTRUCTION AMONG COLLEGE STUDENTS}

The problems in the party construction work among college students not only restrict the level of party construction work, but also directly affect the effectiveness of education of the party construction work. It is a strong guarantee promoting sound development of party construction work among college students to explores the long-term education mechanism of party building work among college students including the construction mechanism of the party construction team, the whole process cultivation mechanism of party members, the innovation mechanism of party construction work by summarizing of the rules and characteristics of the party construction work among college students.

\section{A. Consolidate the Working Foundation to Improve the Construction Mechanism of the Party Construction Team}

In the face of the new situation, new tasks and new challenges, the Party committees in colleges should fully understand the importance of the party staff members, strictly guard the entrance, and strengthen the on-the-job training and assessment to establish a sound construction mechanism of the party construction team, including the construction of three aspects:

1) Access system: The party committee of college level should clearly stipulates that the access requirements for grassroots party workers, including age range, professional background, ideological level and work experience and so on, to fundamentally guarantee the overall quality of party working staff. At the same time, we have to ensure the degree of full-time party workers as much as possible. Especially in the grassroots departments, there should be at least 1-2 fulltime party workers. On the basis of full-time, grass-roots party workers are likely to transform from full-time to specialization, so as to provide the basic guarantee for better party construction among college students.

2) Training system: Colleges and universities should pay attention to the training of grassroots party staff members, and promote the improvement in political quality, ability quality and psychological quality of the party staff members through training of theory, business and skills. At the same time, we can take the measures of "arranging training inside and outside the school, further study and training on a temporary post and so on" to improve the overall quality of the party work team and enhance the working status of the party staff members.

3) Assessment and incentive system: We need to establish a reasonable assessment and evaluation system, clarify and refine the requirements for their ability and quality, and establish an evaluation system composed of the morality, knowledge, ability and culture based on job performance to form the effective restraint and guidance to party workers. At the same time, the party workers with outstanding achievements should be commended and widely publicized, which can play a role of radiation and encouragement in the whole party work team.

\section{B. Center on the Core of Education, Establish and Improve the Whole Process Cultivation Mechanism of Party Members}

The so-called whole process cultivation mechanism of party members refers that making the training process of party members throughout the whole life process of party members, including the five stages: enlightenment of new students to join the party, education and training of party activists, probationary party member and full members and education of graduate party members.

1) Enlightenment Education on new students to join the party: In order to enhance the quality of student party members, we should start to carry out the party construction work when new students enter the colleges, to achieve "early education, early selection and early training." It can be divided into three steps: first is the leading model. We should explore the outstanding teachers and students advanced models of party members, hold the colloquium of advanced deeds to act as an example to others and stimulate the enthusiasm of new students to join the party; the second is on 
the basis of above, we can carry out the basic theoretical knowledge lectures of party, to guide students to get close to the party from the theoretical height. The third is to set up a learning group in the new students who have already submitted the party membership application with the senior party member as the director of the team, to guide and help the new students from the aspects of ideological promotion and professional learning. At the same time, we also need to inspect the ideological level and comprehensive quality of new students.

2) Cultivation and education of party activists: Party activists are the candidates of the party members, so their ideological level and motivation of joining the Party directly affect the quality of party members in colleges. Therefore, the training of the party activists should be started from the foundation. We can carry out training courses for party activist, consolidate the foundation starting from the party's basic theory and basic knowledge and clarify the truth, to strengthen their ideals and beliefs, enhance their party spirit, and correct the motivation to join the party. At the same time, we should organize the party activists to participate in practical training, to test the theoretical knowledge they learned in practice, so as to guide the party activists not only join the party from the organization, but also from the ideology.

3) Cultivation and education of probationary party member: Preparatory party members are equivalent to the party activists who have entered the "door of party ", so they may be relaxed whether ideologically or practically. At this time, we must seize the time to guide the probationary party member to change the wrong consciousness. We can carry out the work from two aspects: one is to organize deeper theoretical study, such as field lesson in the revolutionary memorial museum and education base, and speech contest or debate competition of the party's theoretical knowledge to deepen the probationary party members' understanding of the party's theoretical knowledge. Second is to set up exercise post of probationary party member, such as participating in inspectors team of study style or volunteer service group in the department, to help the probationary party member be "in position" and require themselves according to the standard of party members.

4) Cultivation and education of full member: Compared with the party activists and preparatory party members, education on the full members in colleges are generally at the status of the "laissez faire". However, full members are already the formal members of party organization, so strengthening the education on full members should be the top priority. The specific education forms, compared with that of the preparatory party members, should be deeper in theory and practice. For example, we can encourage the full members to carry out certain theoretical research work to promote the innovation of students' party construction work. At the same time, the full members should bear the education and training work for the party activists and the preparatory party members. Besides, their comprehensive quality can get further improved.

5) Education on graduates party member: Graduate Party members are advanced members of college graduates, as well as the new forces in social and political, economic and cultural undertakings. Accomplishing the education and management work of the graduate Party members can help them confirm the political ideas, stabilize thinking, enhance self-improvement and give full play to the advanced nature of party members. We can also organize graduate party members to participate in the last party class, the last organization life, as well as the theme activities such as "donating books" and "reviewing the oath" and so on, to give full play to the role of model of graduate party members in the employment and civilized departure work, so that they can begin their new job or study with positive attitude and mental outlook and inspire and drive the surrounding students by their own practical action.

\section{KEEP PACE WITH THE TIMES AND CONSTANTLY EXPLORE THE INNOVATION MECHANISM OF PARTY CONSTRUCTION WORK}

In view of the current problems and new situations in the party construction work among college students, colleges should further emancipate the mind, keep pace with the times, update their ideas, explore and innovate to improve the working methods closely combing with the practical work of party construction among students, improve the work content and enhance the effectiveness of party construction work among college students.

\section{A. Combine Theory and Practice and Vigorously Carry out the Research on the Project of Party Construction Work}

We should encourage the party workers, student party branch secretary and backbone of party members to carry out the study on party construction work among students, the content of which can include construction of work team of party construction among students, work content, forms of organization activities and the methods of exerting the advancement of party members. Party committee should provide the funding support and necessary guidance to encourage the enthusiasm of teachers and students to carry out party construction among students. At the same time, we can explore the advanced research through conclusion debate of the project to promote and apply it in practical work, and promote the innovation in party construction work.

\section{B. Change the Thinking to Introduce the Information} Technology into Party Construction Work among Students

In the management of party members, we can develop the management system of party members, to record the contents from the Party membership application, until the transformation of party relations after graduation, and thus achieve the record and management of the life cycle of party members. First, it is convenient to manage and record the relevant information of party members. Second, party members do not have to fill in the form repeatedly, and the 
data in the system can be retrieved and updated at any time. In the education of party members, we can use the network and WeChat public platform, etc. to establish online party branches and party groups, carry out online party members training and party members, etc., enrich the carrier of party construction, and enhance the flexibility and effectiveness of party construction among students.

\section{CONCLUSION}

The party construction work of college students plays the leading role in ideological and political work in colleges, so it plays a vital role in the education work of colleges. In the new historical period, the reform of higher education, the change of college students' ideological state and the rapid development of the Internet have put forward new challenges to the party construction work among college students. How to explore the long-term education mechanism of party construction work based on maintaining the fine tradition to enhance the education effectiveness of party construction work is still a subject worthy of continuous exploration and practice.

\section{REFERENCES}

[1] Li Jingwei. The Construction of the Whole process Training System for College Student Party Members [J]. Journal of Jilin Institute of Chemical Technology. 2015(7): 65-66.

[2] Liao Guifang. Establishing Long-term Mechanism is the Key to Solve the Problem of party construction in colleges [J]. Theory and Practice. 2006(6): 73-74. 